\title{
Diplopods as Soil Bioindicators of Toxicity After Application of Residues From Sewage Treatment Plants and Ethanol Industry
}

\author{
Cintya A. Christofoletti, ${ }^{1,2}$ Annelise Francisco, ${ }^{1}$ Janaína Pedro-Escher, ${ }^{1}$ Vinícius D. Gastaldi, ${ }^{1}$ and \\ Carmem S. Fontanetti ${ }^{1, *}$ \\ ${ }^{1}$ UNESP (São Paulo State University), Institute of Biosciences, Department of Biology, Av. 24-A, $n^{\circ} 1515,13506-900$, Rio Claro, \\ São Paulo, Brazil \\ ${ }^{2}$ Hermínio Ometto University Center (UNIARARAS), Laboratory of Structural Biology, Av. Dr. Maximiliano Baruto, $n^{\circ} 500$, \\ 13607-339, Araras, São Paulo, Brazil
}

\begin{abstract}
Residues like sewage sludge and vinasse have been reused as agricultural fertilizers, but they also present a potential to contaminate soils. Diplopods have been considered excellent bioindicators of soil contamination. In the present study, Rhinocricus padbergi were used to assess toxicity in samples of sewage sludge, biosolids, and sugarcane vinasse. The behavioral analysis, mortality rate, and histological, histochemical, and ultrastructural analyses of the midgut of diplopods were the parameters evaluated. Behaviorally, some diplopods avoided burying themselves after 30 days in soil with biosolid or vinasse. Besides, certain residue combinations were able to cause death of all individuals between 60 and 90 days of exposure. The main tissue responses were significant brush border thickening, induction of epithelial renovation, clustering of hemocytes, accumulation of cytoplasmic granules in hepatic cells, hepatic cells with heteropycnotic nuclei, and cytoplasmic degradation. Alterations were observed at various levels among treatments with different samples and exposure times. Ultrastructural analysis revealed elongation of microvilli coated with a layer of an amorphous substance, resulting in a thicker brush border as observed in the histological analysis. After 30 days of exposure, animals showed an accumulation of spherocrystals in hepatic cells and high absorption of substances, based on the elongation of microvilli. Results obtained in the chemical analysis and the behaviors observed in diplopods suggest that animals processed the residues. Therefore, caution should be exercised in the disposal of these residues in agriculture.
\end{abstract}

Key words: soil toxicity, histopathology, millipedes

\section{INTRODUCTION}

Sewage sludge is a byproduct of wastewater treatment, produced daily in large quantities in urban and industrial centers. It is characterized by high organic matter (OM) content as well as a myriad of xenobiotics in different quantities, depending on the source of sewage (Lambais \& Carmo, 2008). Sewage sludge treatment involves stabilization, and pathogen and volume reduction, resulting in a material termed biosolid, which is considered less harmful than raw sewage sludge (Bertelli, 2007; Artuso et al., 2011).

Vinasse is a byproduct of the sugarcane industry. For each liter of ethanol produced, 10-14 L of vinasse is generated (Granato \& Silva, 2002). Also, for each liter of "cachaça" (Brazilian liquor distilled from sugarcane) produced, 8-10 L of vinasse is generated (Oliveira et al., 2009). This residue is characterized by an acid $\mathrm{pH}$, conferring it corrosive properties, high OM content, and biochemical demand for oxygen, and concentration of salts and metal ions.
Because of these properties, sugarcane vinasse and sewage sludge have a high pollution potential, but are also valuable fertilizers (Silva et al., 2007; Vanzo et al., 2000). Thus, their use in agriculture is promising, but can be very harmful to the environment. Studies on the environmental safety of large-scale land application of these residues have been encouraged, as this practice can have negative effects on nontarget organisms. Bioassays with higher plants, such as the Allium cepa test, have been used to evaluate the toxicity of vinasse and sewage sludge applied according to agricultural regulations (Christofoletti et al., 2012, 2013).

Many species of terrestrial invertebrates have also been used as bioindicators in terrestrial ecotoxicology, especially nematodes (Sochová et al., 2006), earthworms (Natal da Luz et al., 2004), and collembolans (Eom et al., 2007). However, due to an increase in sources of contamination, other species with bioindicator potential have been necessary (Løkke \& Van Gestel, 1998; Eom et al., 2007). Diplopods are important cosmopolitan soil macroinvertebrates capable of colonizing different soil layers, and act as decomposers (Petersen \& Luxton, 1982). Because of these traits and the responsiveness of 
their tissues as biomarkers (Fontanetti et al., 2011), diplopods have been successfully used as bioindicators of soil quality (Godoy \& Fontanetti, 2010; Nogarol \& Fontanetti, 2010, 2011; Perez \& Fontanetti, 2011a; Souza \& Fontanetti, 2011; Bozzatto \& Fontanetti, 2012; Christofoletti et al., 2012; Souza et al., 2014).

This study was aimed at assessing the toxicity of sewage sludge, biosolid, and sugarcane vinasse by behavioral analysis and histopathological alterations observed in the midgut of the diplopod Rhinocricus padbergi exposed to soil mixed with these effluents according to the Brazilian regulations for land application.

\section{Materials and Methods}

\section{Soil}

The soil sample used as control and for mixing with residues was collected at the site where diplopods were obtained at the São Paulo State University (UNESP), Rio Claro campus $\left(22^{\circ} 24^{\prime} 36^{\prime} \mathrm{S} / 47^{\circ} 33^{\prime} 36^{\prime} \mathrm{W}\right)$, São Paulo, Brazil. Two bioassays were set up using soil collected in 2010 and 2011 at a depth of $0.20 \mathrm{~cm}$, previously dried at room temperature, sieved with $4 \mathrm{~mm}$ screen sieve, and chemically characterized.

\section{Sewage Sludge and Biosolid}

Samples of primary sewage sludge and biosolid were collected in 2010 and 2011 in a municipal wastewater treatment plant (WTP) in the state of São Paulo, Brazil. The plant is managed by the Basic Sanitation Company of the State of São Paulo (Companhia de Saneamento Básico do Estado de São Paulo-SABESP). Samples were collected and stored in plastic boxes wrapped in dark plastic bags and placed in a cold room $\left(4^{\circ} \mathrm{C}\right)$, until used in experiments.

\section{Sugarcane Vinasse}

This effluent was collected in a sugarcane processing plant, in the city of Araras, São Paulo, Brazil. After collection, the material was stored in a cold room $\left(4^{\circ} \mathrm{C}\right)$, at the Department of Biochemistry and Microbiology of UNESP-Rio Claro Campus, until being used in experiments.

\section{Chemical Characterization of Samples}

Chemical and physico-chemical characterization of all samples were carried out by the Institute of Campinas of Soil and Fertilizer (Instituto Campineiro de Solo e Adubo-ICASA), Campinas, São Paulo, Brazil and by the Laboratory TASQA, Paulínia, São Paulo, Brazil, according to the methodology described in Christofoletti et al. (2013).

\section{Bioassays with $R$. padbergi}

In the present study, adult individuals of $R$. padbergi averaging $6.0 \mathrm{~cm}$ in size were used in order to avoid interspecific differences associated with diplopod size and/or age. Specimens were collected on the Rio Claro Campus of the São Paulo State
University, state of São Paulo, Brazil. After collection, animals were maintained in the laboratory for 4 weeks in a terrarium containing a mixture of soil, decomposing roots, and tree branches from the collection site. The room temperature was set at $21 \pm 2^{\circ} \mathrm{C}$ and $12 \mathrm{~h}$ light $/ 12 \mathrm{~h}$ dark photoperiod.

Six terraria measuring $20 \mathrm{~cm}$ in width $\times 25 \mathrm{~cm}$ in length and $45 \mathrm{~cm}$ in height were filled with $5 \mathrm{~kg}$ of soil from the site where diplopods were collected and mixed with primary sewage sludge, biosolid, vinasse, and combinations, according to Brazilian laws for land application. After chemical characterization of the samples and fertility analyses of the control soil samples, the following treatments were set up:

2010 collection:

CS $5 \mathrm{~kg}$ of control soil \pm 20 diplopods

SS $5 \mathrm{~kg}$ of control soil $\pm 321.72 \mathrm{~mL}$ of primary sludge 20 diplopods

SB $5 \mathrm{~kg}$ of control soil $\pm 136.58 \mathrm{~g}$ of biosolid \pm 20 diplopods

SV $5 \mathrm{~kg}$ of control soil $\pm 410 \mathrm{~mL}$ of vinasse \pm 20 diplopods

SSV $5 \mathrm{~kg}$ of control soil $+321.72 \mathrm{~mL}$ of primary sludge $\pm 410 \mathrm{~mL}$ of vinasse \pm 20 diplopods

SBV $5 \mathrm{~kg}$ of control soil $\pm 136.58 \mathrm{~g}$ of biosolid $\pm 410 \mathrm{~mL}$ of vinasse \pm 20 diplopods

2011 collection:

CS $5 \mathrm{~kg}$ of control soil \pm 20 diplopods

SS $5 \mathrm{~kg}$ of control soil $\pm 795.49 \mathrm{~mL}$ of primary sludge \pm 20 diplopods

SB $5 \mathrm{~kg}$ of control soil $\pm 234.4 \mathrm{~g}$ of biosolid \pm 20 diplopods

SV $5 \mathrm{~kg}$ of control soil $\pm 65.56 \mathrm{~mL}$ of vinasse \pm 20 diplopods

SSV $5 \mathrm{~kg}$ of control soil $\pm 795.49 \mathrm{~mL}$ of primary sludge $\pm 65.56 \mathrm{~mL}$ of vinasse \pm 20 diplopods

SBV $5 \mathrm{~kg}$ of control soil $\pm 234.4 \mathrm{~g}$ of biosolid $\pm 65.56 \mathrm{~mL}$ of vinasse \pm 20 diplopods

\section{Dissection of Animals}

Animals were exposed for 7, 30, and 90 days to examine the acute (7 days) and subchronic (90 days) response, and an intermediary period (30 days) between them. After each period of exposure, three animals of each treatment were anesthetized with chloroform and dissected in saline solution for insects. The midgut was removed and portions were fixed with Bouin, paraformaldehyde, and formol calcium (Ca) for preparation of the different techniques. After fixation, the material was placed in sodium phosphate buffer $\mathrm{pH} 7.4$ for $24 \mathrm{~h}$ and stored in refrigerator.

\section{Histology and Histochemistry}

For preparation for histological and histochemical techniques, the material was dehydrated in a graded ethanol series (70, 80, 90 and 95\%) and embedded in resin (Leica historesin) for $24 \mathrm{~h}$ in the refrigerator. The material was later transferred to plastic molds filled with resin. After polymerization, $6 \mu \mathrm{m}$ 
Table 1. Classification of the Histopathological Alterations in the Midgut of Diplopods Based on a Semi-Quantitative Evaluation.

\begin{tabular}{llll}
\hline $\begin{array}{l}\text { Region } \\
\text { Examined }\end{array}$ & $\begin{array}{l}\text { Minimum Pathological } \\
\text { Importance (1) }\end{array}$ & Moderate Pathological Importance (2) & Marked Pathological Importance (3) \\
\hline $\begin{array}{l}\text { Epithelium } \\
\text { Hepatic cells }\end{array}$ & Epithelial renovation & $\begin{array}{l}\text { Thickening of the brush border } \\
\text { Increase in the number of granules in } \\
\text { hepatic cells } \\
\text { Increase in the number of hemocytes between } \\
\text { hepatic cells }\end{array}$ & $\begin{array}{c}\text { Heteropycnosis of the nucleus of } \\
\text { hepatic cells } \\
\text { Cytoplasmic degradation }\end{array}$ \\
\hline
\end{tabular}

Factor of importance: (1) minimal pathological importance, damage is easily reversible when the exposure to the irritant ends; (2) moderate pathological importance, damage is reversible in most cases, when the stressor is neutralized; and (3) marked pathological importance, damage is usually irreversible, resulting in partial or total loss of the organ function.

Table 2. Data on the Fertility of the Control Soil for the Two Collections.

\begin{tabular}{|c|c|c|c|c|c|c|c|c|c|c|c|c|}
\hline Collections & $\mathrm{pH}$ & $\begin{array}{c}\mathrm{OM} \\
\left(\mathrm{g} / \mathrm{dm}^{3}\right)\end{array}$ & $\begin{array}{c}\text { P res } \\
\left(\mathrm{mg} / \mathrm{dm}^{3}\right)\end{array}$ & $\underset{\left(\operatorname{mmol}_{\mathrm{c}} / \mathrm{dm}^{3}\right)}{\mathrm{K}}$ & $\begin{array}{c}\mathrm{Ca} \\
\left(\mathrm{mmol}_{\mathrm{c}} / \mathrm{dm}^{3}\right)\end{array}$ & $\underset{\left(\mathrm{mmol}_{\mathrm{c}} / \mathrm{dm}^{3}\right)}{\mathrm{Mg}}$ & $\begin{array}{c}\mathrm{H}+\mathrm{Al} \\
\left(\mathrm{mmol}_{\mathrm{c}} / \mathrm{dm}^{3}\right)\end{array}$ & $\begin{array}{c}\mathrm{SB} \\
\left(\mathrm{mmol}_{\mathrm{c}} / \mathrm{dm}^{3}\right)\end{array}$ & $\begin{array}{c}\text { CTC } \\
\left(\mathrm{mmol}_{\mathrm{c}} / \mathrm{dm}^{3}\right)\end{array}$ & V\% & $\begin{array}{c}\text { Ratio } \\
(\mathrm{Ca} / \mathrm{Mg})\end{array}$ & $\begin{array}{l}\text { Ratio } \\
(\mathrm{Mg} / \mathrm{K})\end{array}$ \\
\hline 2010 & 6.20 & 18 & 3.0 & 0.8 & 2 & 1 & 88 & 3.9 & 91.9 & 4.2 & 2.0 & 1.25 \\
\hline 2011 & 5.10 & 17 & 3.0 & 0.2 & 9 & 6 & 30 & 16.6 & 5.88 & 3.5 & - & - \\
\hline
\end{tabular}

$\mathrm{OM}$, organic matter; CTC, cation exchange capacity; V, base saturation; SB, sum of bases.

sections were obtained with a LEICA RM 2245 microtome (Leica Biosystems Nussloch GmbH, Nussloch, Germany). Sections were hydrated and placed on slides.

For the histological analysis, slides were stained with hematoxylin and eosin. Histochemical staining was performed to detect neutral polysaccharides-periodic acid-Schiff (PAS) (Junqueira \& Junqueira, 1983), total proteins-bromophenol blue (Pearse, 1985), lipids-Nile blue (Junqueira \& Junqueira, 1983), and Ca-von Kossa method (Junqueira \& Junqueira, 1983). Slides were examined with a light microscope.

\section{Analysis of Results}

Histology of the midgut was qualitatively described and histopathological alterations were analyzed semiquantitatively for each diplopod. The protocol followed was based on that proposed by Bernet et al. (1999), by classifying cell pathology into three categories: (1) minimal pathological importance, the lesion is easily reversible as exposure to irritants ends; (2) moderate pathological importance, the lesion is reversible in most cases, when the stressor is neutralized; and (3) marked pathological importance, the lesion is generally irreversible, leading to partial or total loss of organ function. In the present study, this classification was adapted to histopathology of the midgut of diplopods. Table 1 presents the classification used in this study. Scores from 0 to 6 were used to classify the histopathological alterations depending on the level or extent of the alteration: (0) unaltered; (2) small alteration; (4) moderate alteration; and (6) severe alteration. Intermediary scores were also used. Scores $(a)$ were multiplied by the factor of importance of each alteration $(w)$ to define an index of damage (I) per individual. Thus, the index of damage of the different alterations, for each individual was calculated as follows:

$I($ individual $)=a($ score received $) \times w($ factor of importance $)$.

To define the index of damage of each alteration for the control, as well as for each treatment, the sum of indices of damage was obtained for each individual and later the average and standard deviation were calculated.

The data obtained in the semi-quantitative histopathological evaluation were compared with the results obtained for the individuals exposed to the control soil sample with the Kruskal-Wallis test and $p<0.05$.

\section{Ultrastructure}

For the ultrastructural analysis, the material was fixed in $2.5 \%$ glutaraldehyde in $0.1 \mathrm{M}$ sodium cacodylate buffer, $\mathrm{pH} 7.2$ at $4^{\circ} \mathrm{C}$. The material was postfixed in $1 \%$ osmium tetroxide in the same buffer and immersed in uranyl acetate for $8 \mathrm{~h}$. Dehydration was performed with a graded acetone series and samples were embedded in a mixture of epon araldite resin during $12 \mathrm{~h}$ at $4^{\circ} \mathrm{C}$. Thin sections were obtained with an ultramicrotome and contrasted with uranyl acetate and lead citrate for examination and documentation with a ZEISS-EM 900 transmission electron microscope (Carl Zeiss SMT GmbH, Oberkochen, Germany) operated at $80 \mathrm{kV}$, kindly provided by Dr. Elliot W. Kitajima, of the Luiz de Queiroz College of Agriculture-ESALQ, Piracicaba, São Paulo.

\section{RESULTS}

\section{Soil Analysis}

For the correct application of residues, data on the agronomic potential and on the fertility of the control soil 
were necessary. The values obtained for $\mathrm{pH}, \mathrm{OM}$, residual phosphorus, potassium, $\mathrm{Ca}$, magnesium, exchangeable aluminum, sum of bases (SB), cation exchange capacity, and base saturation for the two soil collections varied and are presented in Table 2 .

Comparison and Chemical Characterization of the Control Soil and Raw Residue Samples

Results obtained for the physico-chemical and metal analyses for the control soil and residues, as well as a comparison of these parameters for the two collections, are presented in Table 3. Because of their complexity, all parameters analyzed for the two soil collections varied. In the second soil collection, different results were obtained for copper, chromium, mercury, molybdenum, and nickel. Metals in samples of primary sludge and biosolid also had concentrations lower than those allowed in the 375/2006 resolution of Brazilian National Council of the Environment (CONAMA) for disposal of sewage sludge and/or biosolid.

Unlike chemical analysis of the first bioassay, in which three organic compounds, phenanthrene, fluoranthene, and naphthalene, were detected in the sample of primary sewage sludge, these compounds were not detected in the chemical analysis of the sample used in the second bioassay. This analysis was also performed for samples of raw biosolid and control soil. However, no organic compounds were detected in these samples, in both bioassays performed.

Comparison of Results Obtained with the Physico-Chemical and Metal Analyses for the Combinations of Primary Sludge, Biosolid, and Vinasse, Before and After Exposure to Diplopods for Both Bioassays

Results obtained for the physico-chemical and metal analyses for the control soil and combinations of residues, before and after 30 days of exposure to diplopods, for both bioassays conducted are presented in Table 4 . Based on these analyses, alternation of accumulation and/or availability of metals was observed for all samples. The $\mathrm{pH}$ values varied slightly. Other elements, such as barium, total phosphorus, and total calcium varied (decrease or increase) for all samples.

\section{Bioassays with $R$. padbergi}

Behavioral Analysis and Mortality of Diplopods Exposed to Sewage Sludge, Biosolid, Vinasse, and Combinations

The behavior of diplopods, such as the ability to bury themselves or to remain on the surface, and the rate of mortality of these animals exposed to combinations of residues, were observed since the beginning of experiments.

In both bioassays, the control group exhibited normal behavior described for the species: animals were buried in the soil during the day, and were active at night. Also, based on the behavioral analysis, animals did not avoid the soil mixed with different residues until the 30th day of exposure. After this period, animals of from SS and SB treatments often did not buried themselves and there were always some animals on the surface.

Regarding mortality rate, SSV and SBV of the first bioassay, and $\mathrm{SB}$ of the second bioassay were the most toxic, inducing the death of all individuals between 60 and 90 days of exposure (Table 5).

\section{Histology, Histochemistry and Ultrastructure}

Control Group. The histological and histochemical patterns of the midgut of animals of the control group from both bioassays was typical for the species (Fantazzini et al., 2002), characterized by a pseudostratified epithelium with brush border, followed by a muscle layer and a layer of hepatic cell. Underneath hepatic cells, a discontinuous muscle layer is observed, and an external membrane encloses the entire structure (Fig. 1a). Hepatic cells exhibit irregular morphology, spherical nuclei, and heterogeneous cytoplasm with granules of various aspects (arrows in Figs. 1a, 1b, and 1d). Between hepatic cells, some hemocytes, usually isolated, are observed (Fig. 1b).

Neutral polysaccharides were detected in the brush border, which is $2.87 \mu \mathrm{m}$ thick, in the basal membrane, and in the layer of hepatic cells (Fig. 1b). Principal cells and hepatic cells were moderately stained for proteins (Fig. 1c). Lipids were detected in the medial-apical region of the cytoplasm of principal cells of the epithelium and hepatic cells (Fig. 1d). The von Kossa method revealed the distribution of calcium in the principal cells of the epithelium as fine granules (Fig. 1e).

Ultrastructural characteristics of the midgut of diplopods were in agreement with the pattern described for the species (Camargo-Mathias et al., 2004). The epithelium consists of principal or absorptive cells, regenerative cells, and secretory cells. Absortive cells present a large number of microvilli on the free surface with cytoplasm rich in rough endoplasmic reticulum and mitochondria located mainly in the apical region (Figs. 2a-2c). Regenerative cells may be present at the base of the epithelium, between absorptive cells, and exhibit cytoplasm less electron dense than those of principal cells, with abundant mitochondria. The hepatic cells have heterogeneous cytoplasm. Among these cells are observed several tracheoles and hemocytes (Fig. 2b).

Group Exposed to the Different Combinations of Residues in the Three Time Periods for Both Bioassays. The midgut of exposed animals from all treatments of both bioassays at 7 days exhibited epithelial renovation (Figs. 3a, 3b).

After 30 days of exposure, a thickening of the brush border was observed (arrowhead in Fig. 3c) and an accumulation of cytoplasmic granules in hepatic cells (arrowheads in Fig. 3d), for animals from SB, in both bioassays. Also, a high content of polysaccharides in hepatic cells (Fig. 3e) was demonstrated by the PAS technique. Some cytoplasmic granules were stained for calcium (arrows in Fig. 3f). The SV, SSV, and SBV treatments of both bioassays still induced epithelial renovation 
Table 3. Physico-Chemical and Metal Analysis of the Control Soil and Raw Samples of Vinasse, Primary Sludge, and Biosolid, for Both Collections.

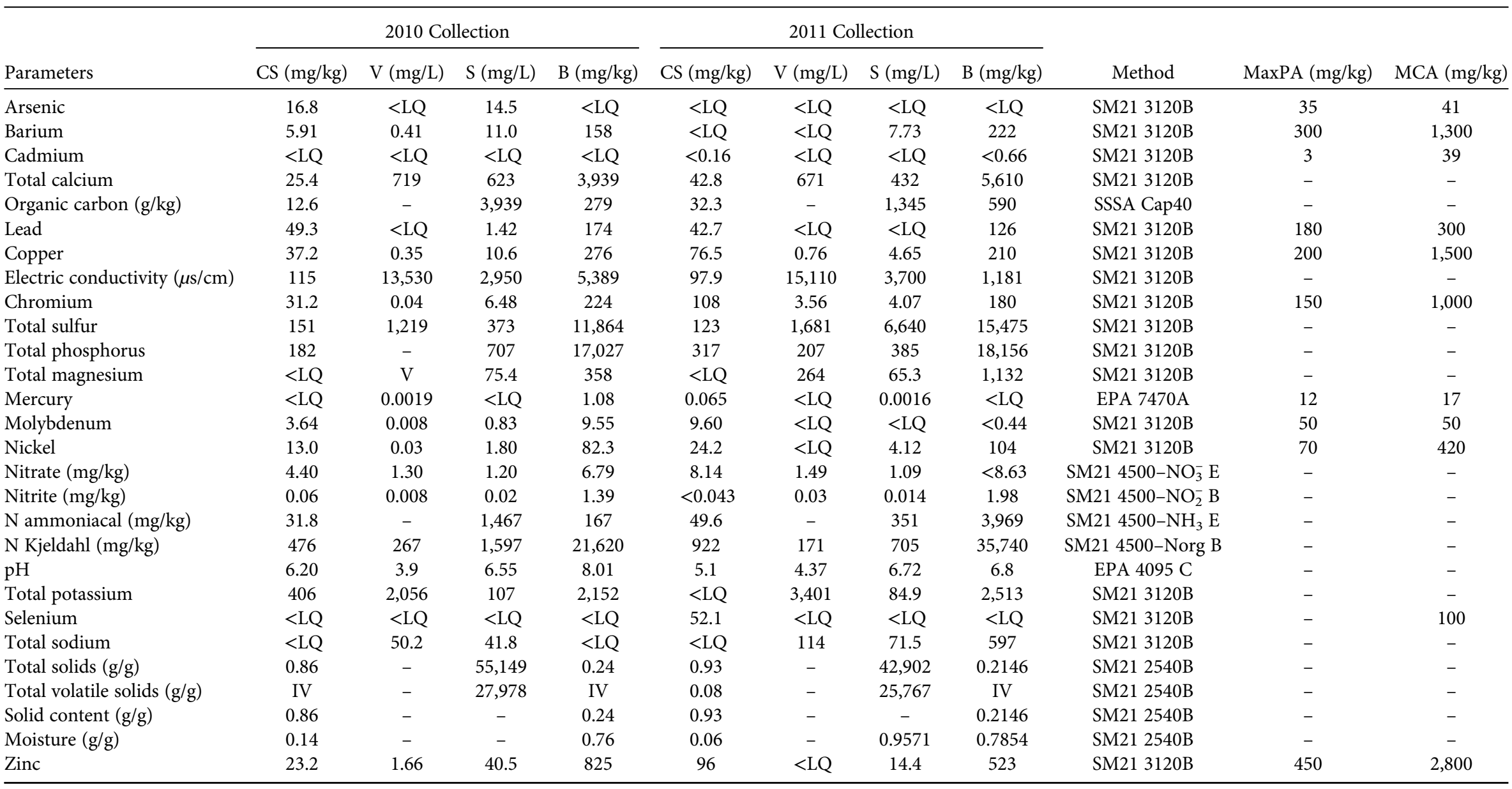

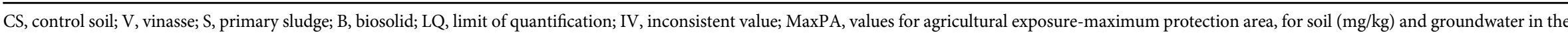

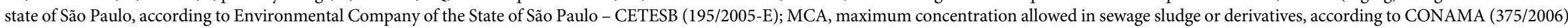




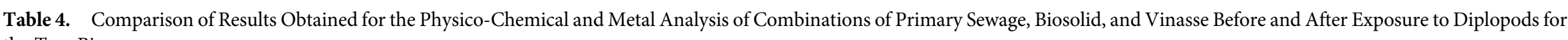
the Two Bioassays.

\begin{tabular}{|c|c|c|c|c|c|c|c|c|c|c|c|c|c|c|c|c|c|c|c|c|c|c|c|c|}
\hline \multirow[b]{4}{*}{ Parameters } & \multicolumn{24}{|c|}{ Treatments } \\
\hline & \multicolumn{4}{|c|}{ CS } & \multicolumn{4}{|c|}{ SS } & \multicolumn{4}{|c|}{ SB } & \multicolumn{4}{|c|}{ SV } & \multicolumn{4}{|c|}{ SSV } & \multicolumn{4}{|c|}{ SBV } \\
\hline & \multicolumn{2}{|c|}{2010} & \multicolumn{2}{|c|}{2011} & \multicolumn{2}{|c|}{2010} & \multicolumn{2}{|c|}{2011} & \multicolumn{2}{|c|}{2010} & \multicolumn{2}{|c|}{2011} & \multicolumn{2}{|c|}{2010} & \multicolumn{2}{|c|}{2011} & \multicolumn{2}{|c|}{2010} & \multicolumn{2}{|c|}{2011} & \multicolumn{2}{|c|}{2010} & \multicolumn{2}{|c|}{2011} \\
\hline & T0 & T30 & T0 & T30 & T0 & T30 & T0 & T30 & T0 & T30 & T0 & T30 & T0 & T30 & T0 & T30 & T0 & T30 & T0 & T30 & T0 & T30 & T0 & T30 \\
\hline Arsenic & 16.8 & $<$ LQ & $<\mathrm{LQ}$ & $<\mathrm{LQ}$ & 6.74 & $<\mathrm{LQ}$ & $<\mathrm{LQ}$ & $<\mathrm{LQ}$ & 3.49 & $<$ LQ & $<\mathrm{LQ}$ & $<\mathrm{LQ}$ & 5.79 & $<\mathrm{LQ}$ & $<\mathrm{LQ}$ & $<\mathrm{LQ}$ & $<\mathrm{LQ}$ & $<\mathrm{LQ}$ & $<\mathrm{LQ}$ & $<\mathrm{LQ}$ & 10.5 & $<\mathrm{LQ}$ & $<\mathrm{LQ}$ & $<\mathrm{LQ}$ \\
\hline Barium & 5.91 & 11.3 & $<\mathrm{LQ}$ & 6.93 & 7.76 & 12.0 & 8.03 & 6.7 & 6.21 & 15.2 & 8.40 & 7.47 & 6.50 & 12.9 & 7.21 & 6.06 & 7.22 & 7.43 & 8.2 & 6.47 & 7.07 & 8.99 & 6.18 & 7.49 \\
\hline Cadmium & $<$ LQ & $<$ LQ & $<0.16$ & $<0.18$ & $<\mathrm{LQ}$ & $<\mathrm{LQ}$ & $<0.19$ & $<0.18$ & $<$ LQ & $<$ LQ & $<0.17$ & $<0.18$ & $<\mathrm{LQ}$ & $<\mathrm{LQ}$ & $<0.17$ & $<0.19$ & $<\mathrm{LQ}$ & $<\mathrm{LQ}$ & $<0.17$ & $<0.18$ & $<$ LQ & $<\mathrm{LQ}$ & 0.3 & $<0.18$ \\
\hline Total calcium & 25.4 & 170 & 42.8 & 2.43 & 24.5 & 242 & 49.2 & $<\mathrm{LQ}$ & 30.8 & 350 & 54 & $<\mathrm{LQ}$ & 29.3 & 246 & 36.5 & $<\mathrm{LQ}$ & 41.7 & 96.5 & 35.6 & $<\mathrm{LQ}$ & 26.7 & 97.3 & 37.6 & 3.04 \\
\hline Organic carbon $(\mathrm{g} / \mathrm{kg})$ & 12.6 & 91.8 & 32.3 & 47.9 & 33.3 & 128 & 34.3 & 42.1 & 35.2 & 118 & 33.9 & 48.5 & 28.8 & 81.7 & 27.5 & 40.9 & 22.3 & 59.3 & 26.8 & 42.7 & 17.5 & 63.1 & 33.4 & 55.4 \\
\hline Lead & 49.3 & 10.0 & 42.7 & 7.27 & 15.7 & 16.2 & 86.8 & 9.69 & 14.8 & 16.6 & 88.9 & 3.3 & 8.46 & 4.83 & 89.2 & 4.39 & 10.0 & 5.94 & 82.8 & 5.56 & 6.17 & 13.0 & 71.1 & 5.78 \\
\hline Copper & 37.2 & 68.4 & 76.5 & 43.6 & 62.3 & 75.7 & 54.1 & 41.6 & 67.8 & 93.6 & 59.3 & 93,6 & 58.2 & 70.2 & 64.2 & 49.5 & 40.7 & 51.6 & 59.1 & 52 & 38.1 & 47.1 & 56.9 & 48.9 \\
\hline Chromium & 31.2 & 26.5 & 108 & 25.3 & 25.1 & 26.3 & 27.9 & 23.9 & 28.6 & 30.6 & 29.4 & 47.9 & 25.2 & 25.6 & 28.3 & 22.8 & 20.1 & 21.8 & 28.3 & 24 & 31.5 & 22.8 & 28.4 & 25.6 \\
\hline Total phosphorus & 182 & 262 & 317 & 295 & 350 & 335 & 390 & 351 & 373 & 444 & 395 & 354 & 317 & 267 & 348 & 288 & 298 & 224 & 410 & 357 & 262 & 274 & 397 & 436 \\
\hline Mercury & $<\mathrm{LQ}$ & $<\mathrm{LQ}$ & 0.06 & 0.03 & 0.09 & $<\mathrm{LQ}$ & 0.17 & 0.04 & 0.10 & $<\mathrm{LQ}$ & $<\mathrm{LQ}$ & 0.04 & 0.20 & $<\mathrm{LQ}$ & 0.04 & 0.04 & 0.37 & $<\mathrm{LQ}$ & 0.04 & 0.04 & 0.04 & $<\mathrm{LQ}$ & 0.19 & 0.05 \\
\hline Molybdenum & 3.64 & $<\mathrm{LQ}$ & 9.6 & $<0.12$ & $<\mathrm{LQ}$ & $<\mathrm{LQ}$ & 1.54 & $<0.12$ & 3.99 & 2.56 & 0.57 & $<0.12$ & 1.58 & 3.34 & 2.46 & $<0.13$ & 1.70 & $<\mathrm{LQ}$ & 2.09 & $<0.12$ & 2.34 & $<\mathrm{LQ}$ & 2.24 & $<0.12$ \\
\hline Nickel & 13.0 & 9.70 & 24.2 & 10.3 & 10.7 & 10.1 & 13.3 & 10.1 & 10.6 & 14.6 & 13.5 & 11.8 & 9.76 & 11.4 & 15 & 10.8 & 5.05 & 7.31 & 14.6 & 12.7 & 7.08 & 8.49 & 12.6 & 11.9 \\
\hline Nitrate & 4.40 & 2.98 & 8.14 & 34.7 & 3.17 & 1.87 & 19.4 & 128 & 2.98 & 4.47 & 19.2 & 33.1 & 3.71 & 2.31 & 14.4 & 56.8 & 1.49 & 3.77 & 15.3 & 116 & $<\mathrm{LQ}$ & 2.70 & 22.5 & 132 \\
\hline $\mathrm{pH}$ & 6.20 & 5.85 & 5.1 & 6.1 & 5.22 & 6.15 & 5.85 & 6.8 & 6.80 & 7 & 5.9 & 5.4 & 4.49 & 3.99 & 5.55 & 5.7 & 6.02 & 5.74 & 5.4 & 5,3 & 4.46 & 5.84 & 5.5 & 6.3 \\
\hline Selenium & $<$ LQ & $<$ LQ & 52.1 & $<\mathrm{LQ}$ & $<\mathrm{LQ}$ & $<\mathrm{LQ}$ & $<\mathrm{LQ}$ & $<\mathrm{LQ}$ & $<$ LQ & $<$ LQ & $<\mathrm{LQ}$ & $<\mathrm{LQ}$ & $<\mathrm{LQ}$ & $<\mathrm{LQ}$ & $<\mathrm{LQ}$ & $<\mathrm{LQ}$ & $<\mathrm{LQ}$ & $<\mathrm{LQ}$ & $<\mathrm{LQ}$ & $<\mathrm{LQ}$ & $<$ LQ & $<\mathrm{LQ}$ & $<\mathrm{LQ}$ & $<\mathrm{LQ}$ \\
\hline Solid contents & 0.86 & 0.83 & 0.93 & 0.78 & 0.82 & 0.83 & 0.80 & 0.82 & 0.89 & 0.82 & 0,85 & 0.80 & 0.79 & 0.89 & 0.83 & 0.79 & 0.80 & 0.89 & 0.84 & 0.79 & 0.84 & 0.85 & 0.83 & 0.79 \\
\hline Zinc & 23.2 & 44.2 & 96 & 47 & 40.5 & 49.3 & 55.7 & 43.2 & 41 & 60.1 & 56.9 & 44.3 & 37.3 & 42.2 & 57 & 45 & 30.8 & 35.2 & 57 & 49.9 & 31.3 & 37.4 & 54.7 & 61.4 \\
\hline
\end{tabular}

CS, control soil; SS, soil + sewage sludge; SB, soil + biosolid; SV, soil + vinasse; SLV, soil + sewage sludge + vinasse; SBV, soil + biosolid + vinasse; LQ, limit of quantification.

Values for metals, calcium, total phosphorus, nitrate $(\mathrm{mg} / \mathrm{kg})$, organic carbon $(\mathrm{g} / \mathrm{kg})$. 
Table 5. Number of Dead Diplopods, After Exposure to the Different Combinations of Residues.

\begin{tabular}{|c|c|c|c|c|c|c|c|c|c|}
\hline \multirow[b]{3}{*}{ Treatments } & \multirow[b]{3}{*}{$n$} & \multicolumn{8}{|c|}{ Mortality } \\
\hline & & \multicolumn{2}{|c|}{7 days } & \multicolumn{2}{|c|}{$\begin{array}{c}\text { 7th-21st } \\
\text { day }\end{array}$} & \multicolumn{2}{|c|}{$\begin{array}{l}\text { 21st-60th } \\
\text { day }\end{array}$} & \multicolumn{2}{|c|}{ 60th-90th day } \\
\hline & & 2010 & 2011 & 2010 & 2011 & 2010 & 2011 & 2010 & 2011 \\
\hline CS & 11 & 0 & 0 & 2 & 3 & 3 & 2 & 3 & 2 \\
\hline SS & 11 & 3 & 0 & 2 & 4 & 4 & 6 & 1 & 0 \\
\hline SB & 11 & 1 & 3 & 3 & 0 & 2 & 8 & 4 & All dead \\
\hline SV & 11 & 0 & 3 & 4 & 2 & 2 & 4 & 3 & 0 \\
\hline SSV & 11 & 0 & 3 & 0 & 1 & 9 & 4 & All dead & 0 \\
\hline SBV & 11 & 0 & 3 & 0 & 2 & 2 & 4 & All dead & 0 \\
\hline
\end{tabular}

$n$, Total number of diplopods per terrarium, excluded animals that were dissected for histological, histochemical, and ultrastructural analyses; CS, control soil; SS, soil + sewage sludge; SB, soil + biosolid; SV, soil + vinasse; SLV, soil + sewage sludge + vinasse; SBV, soil + biosolid + vinasse.

in the midgut of animals. An increase in isolated hemocytes was also observed in samples of SS, SB, and SBV.

After 90 days of exposure, the SB treatment induced thickening of the brush border (arrowheads in Figs. 3c, 3d). The increase was approximately threefold, measuring
$9.13 \mu \mathrm{m}$. Accumulation of cytoplasmic granules in hepatic cells of animals (arrows in Fig. 3b) was observed in the first bioassay. Animals of the SV group exhibited an intense process of epithelial renovation, and an increase in the number of clusters of hemocytes (Fig. 3e), as well as hepatic cells with heteropyknotic nuclei and cytoplasmic degradation (arrows in Fig. 3b). In SS treatment only one individual survived and had his midgut evaluated. The alterations observed were epithelial renewal and accumulation of granules in hepatic cells. However, as it is a single individual, he was not included in the statistical analysis.

Regarding the histochemical pattern, no alterations were observed.

The averages and standard deviations of the sums of alterations observed for both bioassays are presented in Table 6 .

The ultrastructural analysis demonstrated the elongation of microvilli in the absorptive cells and a thicker layer of amorphous substance overlaying (Fig. 2d).

\section{Discussion}

Studies on land application of sewage sludge and vinasse are mainly focused on the effects on soil fertility, as they provide nutrients and increase the dry mass production of several crops (Bettiol et al., 1983; Bettiol \& Ghini, 2011), and the
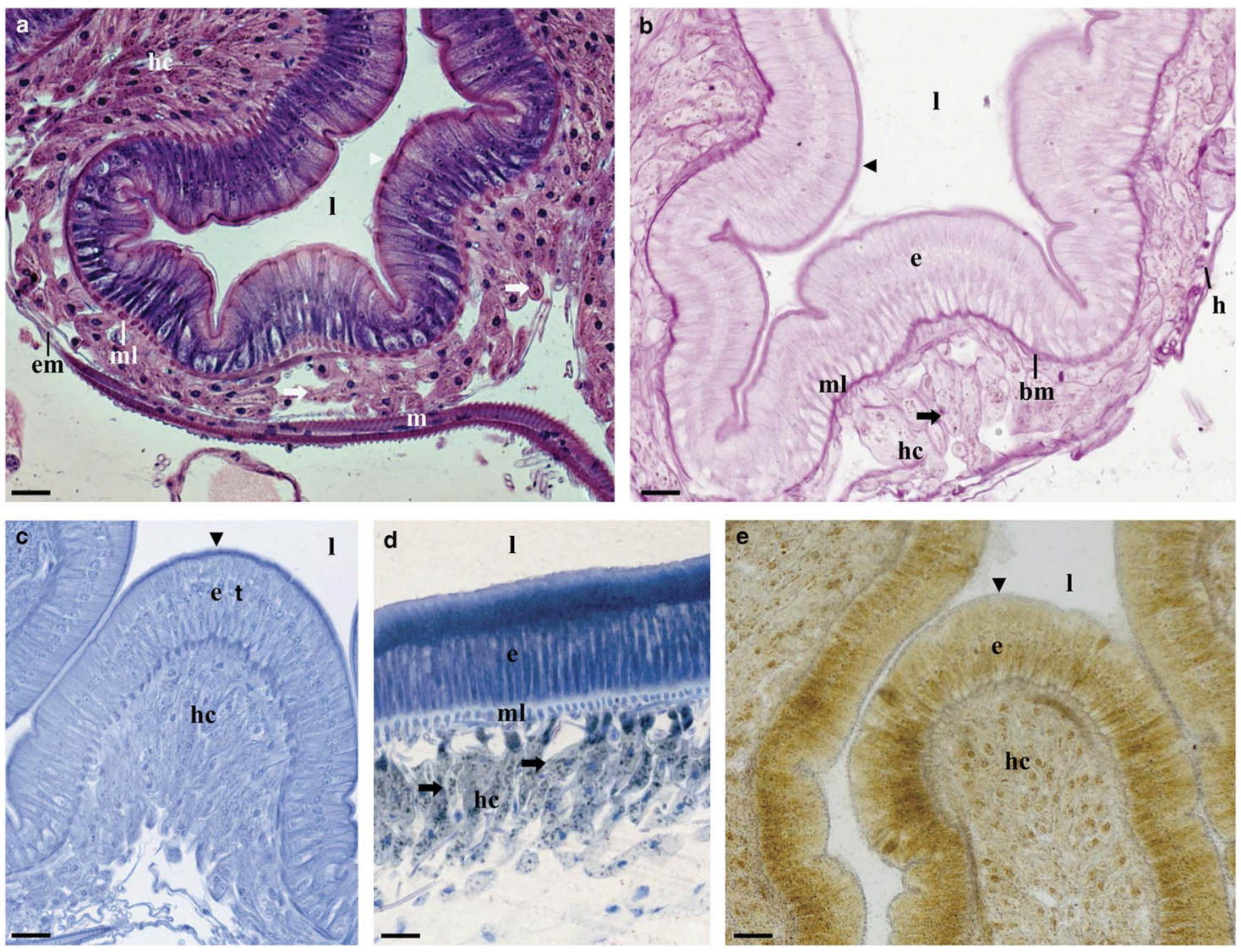

Figure 1. Rhinocricus padbergi midgut exposed to control soil sample and subjected to hematoxylin and eosin (a), periodic acid-Schiff (b), bromophenol blue (c), Nile blue (d), and von Kossa (e) techniques. hc, Hepatic cells; ml, muscle layer; e, epithelium; h, hemocyte; l, lumen; m, muscle; bm, basal membrane, em, external membrane; arrowhead, brush border; arrows, cytoplasmic granules. Scale bar is $20 \mu \mathrm{m}$. 


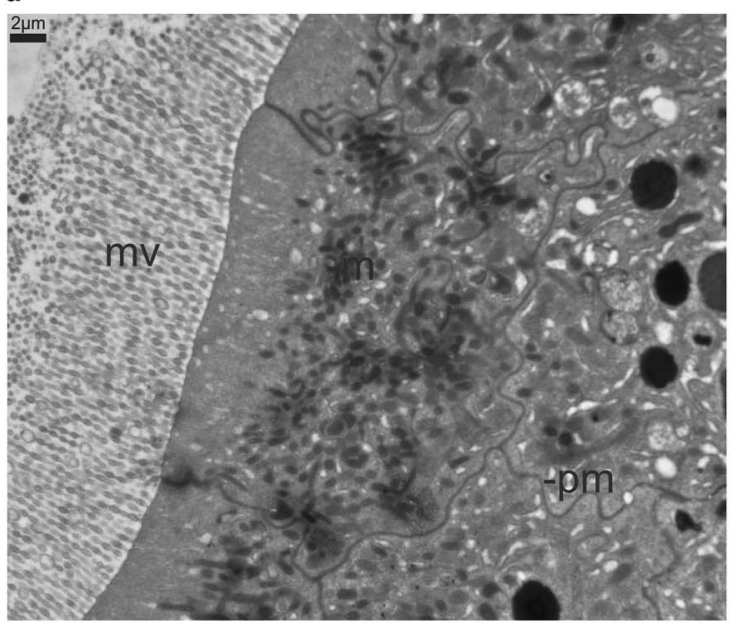

c

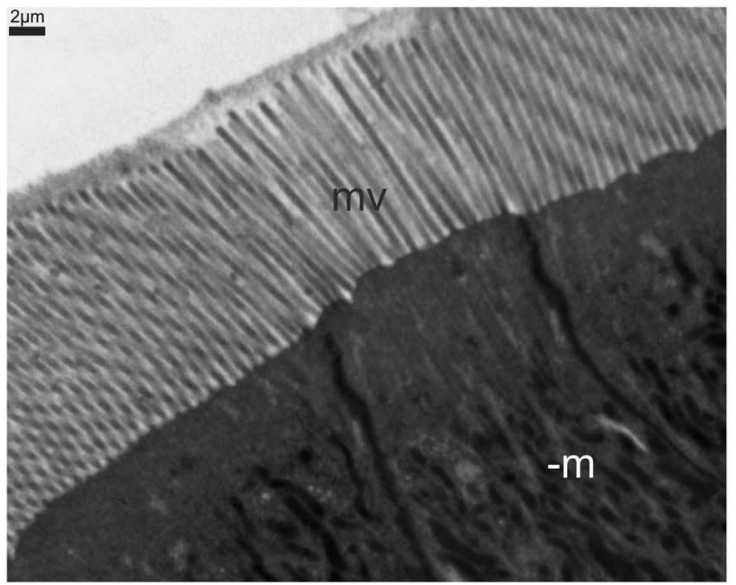

b

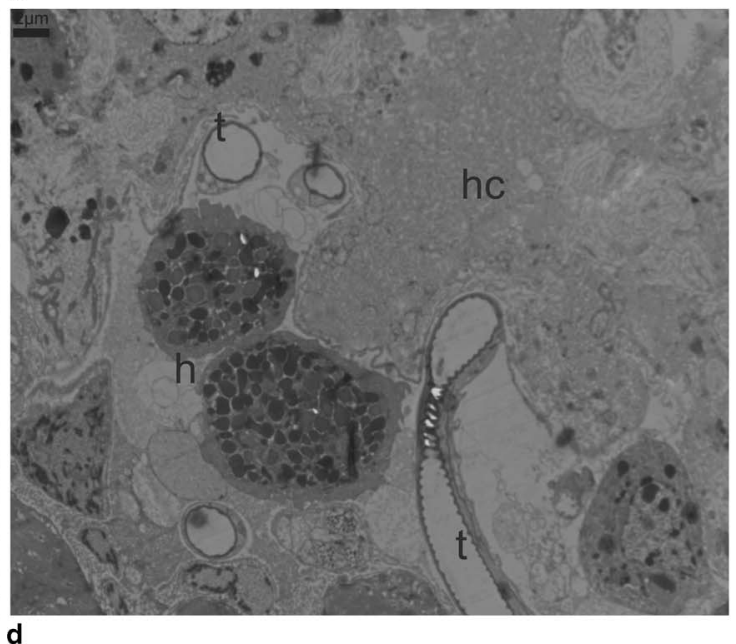

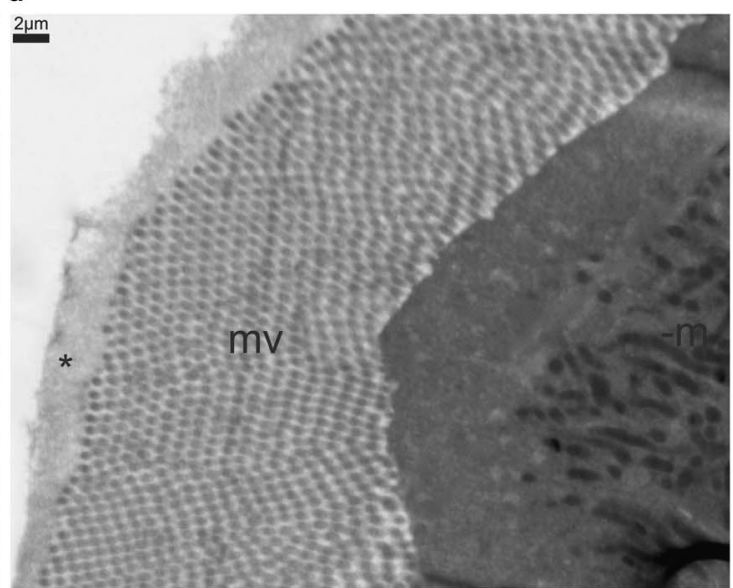

Figure 2. Ultrastructural analysis of Rhinocricus padbergi midgut exposed to control soil sample (a,b,c) and in different combinations of residues (d). h, Hemocyte; hc, hepatic cell; $\mathrm{m}$, mitochondria; mv, microvilli; pm, plasmic membrane; $\mathrm{t}$, tracheole; ${ }^{\star}$, amorphous substance.

accumulation of heavy metals in soils treated with sewage sludge (McBride, 1995; Martins et al., 2003) and vinasse (Brito et al., 2007; Camilotti et al., 2007). Few studies have focused on the toxic potential of these compounds on the different exposed organisms, such as plants and terrestrial invertebrates.

The chemical composition of these residues is very peculiar and complex, as it reflects the peculiarities of a given region. Thus, a chemical analysis is very important in order to know which elements are present in vinasse, sewage sludge, and in the soil, before disposal in the terrestrial environment. However the chemical analysis of the contaminants in geo-environmental samples only measures the concentration of the toxic element or substance, and does not reflect its real bioavailability (Cesar et al., 2008). For this, toxicity tests are performed, which are based on the analysis of adverse effects (lethal and sub-lethal) caused to bioindicators exposed to contaminants under controlled experiments in the laboratory (Lanno et al., 2003).

The evaluation of these responses in ecotoxicological studies has provided interesting results regarding the action of chemicals/contaminants in different organisms. Thus, several authors have recommended the use of a group of biomarkers in different levels of biological organization (Dittbrenner et al., 2011).

Based on the chemical analysis and behavioral evaluation of diplopods, animals interacted with the substrate of all terraria and were able to make large quantities of organic carbon available in all treatments, including the control terrarium. However, according to Suthar (2010), some factors such as microclimatic variability (moisture level, temperature) and substrate depth, among others, may be responsible for the mineralization and/or assimilation of organic carbon. An increase in organic carbon and nitrate was observed in all treatments, corroborating the reported by Schubart (1942) and Godoy \& Fontanetti (2010) that found that diplopods enrich the soil with nitrates. In addition, organic materials may form soluble or insoluble complexes with metals, directly affecting their availability (Stevenson, 1982). This relationship can be observed in the levels of micronutrients and metals of all treatments. Compared with raw samples, levels were lower at T0 and higher after 30 days. These results suggest the bioprocessing of these samples after diplopods, where bioprocessing means that diplopods can remove some xenobiotics from the $\mathrm{OM}$ and reduce its toxicity while they decompose it. 

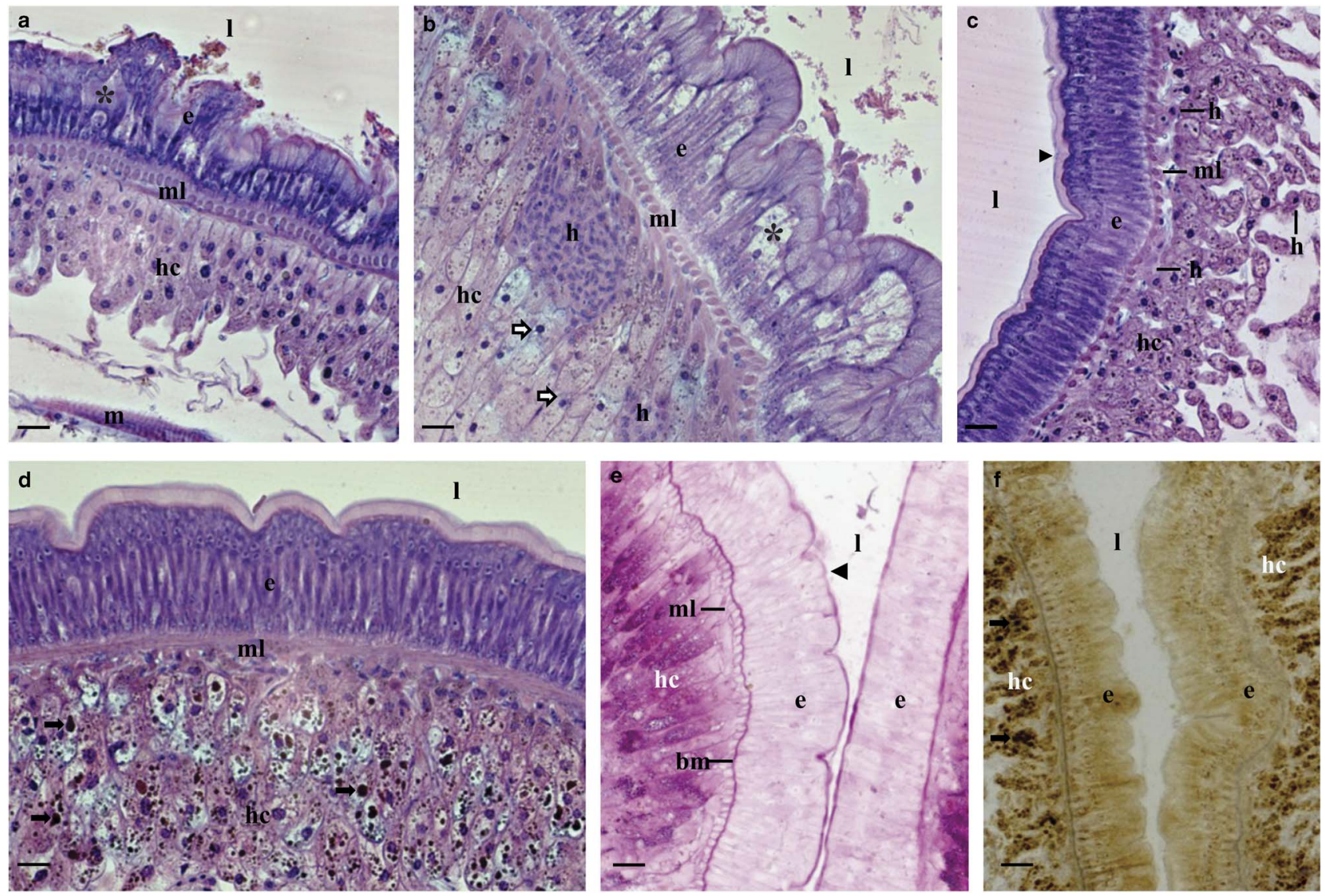

Figure 3. Major tissue alterations observed in the Rhinocricus padbergi midgut exposed to different combinations of residues and subjected to hematoxylin and eosin (a,b,c,d), periodic acid-Schiff (e), and von Kossa (f) techniques. hc, Hepatic cells; ml, muscle layer; e, epithelium; m, muscle; h, hemocyte; l, lumen; bm, basal membrane; arrowhead, brush border; black arrows, cytoplasmic granules; white arrows, heteropycnotic nuclei with cytoplasm degradation; *, epithelial renovation. Scale bar is $20 \mu \mathrm{m}$.

Köhler (2002) and Souza \& Fontanetti (2011) say in invertebrates, intracellular accumulation of potentially toxic compounds in insoluble forms and in physiologically inactive ones is an efficient mechanism for detoxification of these elements. In diplopods, the midgut and the hepatic cells work actively in this process (Köhler, 2002; Nogarol \& Fontanetti, 2010; Christofoletti et al., 2013). According to Cortet et al. (1999), bioaccumulation of metals by terrestrial invertebrates depends on the element, its concentration in the environment, and the physico-chemical conditions of the soil. Nakamura \& Taira (2005) and Nakamura et al. (2005) suggested that diplopods might provide information on the accumulation and regulatory mechanisms of harmful metals present in the environment.

Diplopods do not release barium. This change can be explained by the soil microorganism action as also discussed by Gonçalves et al. (2008) and Magalhães et al. (2011). When soils are wet, microbial metabolism and balance of elements and compounds change, triggering a series of transformations, mainly chemical and microbiological that lead to a new state of equilibrium of the environment, with very different characteristics from those found initially (Gonçalves et al., 2008; Magalhães et al., 2011). Also, according to these authors, this new chemical environment is of great ecological importance, as the change in redox state modifies the bioavailability and mobility of the different elements present in the soil.

Morphological alterations may be used in studies on the toxicity of specific chemical compounds and the monitoring of acute and chronic effects in impacted environments (Meyers \& Hendricks, 1985). Analyses involving the morphology and histology of tissues of invertebrates have been frequently used in the identification of different types of damage caused by harmful substances to individuals (Triebskorn et al., 1991, 1999; Köhler \& Triebskorn, 1998; Fontanetti et al., 2010). However, most studies on the histopathology of the midgut of diplopods exposed to different samples of sewage sludge, landfarming, and herbicides were focused on the qualitative alterations observed in this organ (Nogarol \& Fontanetti, 2010, 2011; Christofoletti et al., 2012; Merlini et al. 2012; Perez \& Fontanetti, 2011a, Souza \& Fontanetti, 2011). According to Dittbrenner et al. (2011), it is crucial to combine a qualitative description of histological conditions and a semi-quantitative analysis in order to better classify the effects observed.

In the present study, the histological analysis revealed that the epithelium of diplopods was affected by the exposure to sewage sludge, biosolid, and vinasse after 7 days. According to Walker (1976), the epithelium is the first line of defense 
Table 6. Mean and Standard Deviation of Alterations Observed in the Midgut of Rhinocricus padbergi Exposed to Different Combinations of Residues at 7, 30, and 90 Days, for Both Bioassays.

\begin{tabular}{|c|c|c|c|c|c|c|c|c|}
\hline \multirow[b]{2}{*}{ Year } & \multirow[b]{2}{*}{ Period } & \multirow[b]{2}{*}{ Treament } & \multicolumn{5}{|c|}{ Alterations } & \multirow[b]{2}{*}{ Sum of Alterations } \\
\hline & & & ER & GR & $\mathrm{HE}$ & $\mathrm{BB}$ & PYC & \\
\hline \multirow[t]{18}{*}{2010} & \multirow[t]{6}{*}{7 days } & CS & $1 \pm 0$ & - & - & - & - & $1 \pm 0$ \\
\hline & & SS & $1.6 \pm 0.57$ & - & - & - & - & $1.6 \pm 0.57$ \\
\hline & & SB & $2.6 \pm 0.57$ & - & - & - & - & $2.6 \pm 0.57^{\star}$ \\
\hline & & SV & $2 \pm 0$ & - & - & - & - & $2 \pm 0$ \\
\hline & & SSV & $2 \pm 0$ & - & - & - & - & $2 \pm 0$ \\
\hline & & SBV & $4.33 \pm 0.57$ & - & - & - & - & $4.33 \pm 0.57^{\star}$ \\
\hline & \multirow[t]{6}{*}{30 days } & CS & $1 \pm 0$ & $0.66 \pm 0.57$ & - & - & - & $1.66 \pm 0.57$ \\
\hline & & SS & $1.66 \pm 0.57$ & - & $2 \pm 0$ & - & - & $3.66 \pm 0.57^{\star}$ \\
\hline & & SB & $2.33 \pm 0.57$ & $6 \pm 3.46$ & $2 \pm 0$ & $5.33 \pm 3.05$ & - & $15.66 \pm 2.88^{\star}$ \\
\hline & & SV & $4 \pm 1$ & - & - & - & - & $4 \pm 1^{*}$ \\
\hline & & SSV & $5.66 \pm 1.57$ & - & - & - & - & $5.66 \pm 1.57^{\star}$ \\
\hline & & SBV & $3.66 \pm 0.57$ & - & $6 \pm 2$ & - & - & $9.66 \pm 2.08^{\star}$ \\
\hline & \multirow[t]{6}{*}{90 days } & CS & $2 \pm 0$ & $1.33 \pm 1.15$ & - & - & - & $3.33 \pm 1.15$ \\
\hline & & SS & $5.5 \pm 0.7$ & $0.66 \pm 1.15$ & - & - & - & $6.5 \pm 0.7^{\star}$ \\
\hline & & SB & - & $5 \pm 1.41$ & - & $6 \pm 2.82$ & - & $11 \pm 1.41^{\star}$ \\
\hline & & SV & $6 \pm 0$ & - & $8 \pm 2.82$ & - & $13.5 \pm 2.12$ & $27.5 \pm 2.94^{\star}$ \\
\hline & & SSV & - & - & - & - & - & All dead \\
\hline & & SBV & - & - & - & - & - & All dead \\
\hline \multirow[t]{18}{*}{2011} & \multirow[t]{6}{*}{7 days } & CS & $0.66 \pm 0.57$ & - & - & - & - & $0.66 \pm 0.57$ \\
\hline & & SS & $3.33 \pm 0.57$ & - & - & - & - & $3.33 \pm 0.57^{\star}$ \\
\hline & & SB & $5 \pm 1$ & - & - & - & - & $5 \pm 1^{\star}$ \\
\hline & & SV & $3.66 \pm 0.57$ & - & - & - & - & $3.66 \pm 0.57^{\star}$ \\
\hline & & SSV & $3 \pm 1$ & - & - & - & - & $3 \pm 1^{\star}$ \\
\hline & & SBV & $3 \pm 1$ & - & $4 \pm 2$ & - & - & $7 \pm 2.64^{\star}$ \\
\hline & \multirow[t]{6}{*}{30 days } & $\mathrm{CS}$ & $1 \pm 0$ & $1.33 \pm 1.15$ & - & - & - & $2.33 \pm 1.15$ \\
\hline & & SS & $2.33 \pm 0.57$ & - & $2.66 \pm 2.3$ & - & - & $4.99 \pm 1.73$ \\
\hline & & SB & $2.33 \pm 0.57$ & - & $3.33 \pm 2.71$ & $8.66 \pm 2.03$ & - & $14.32 \pm 4.51^{\star}$ \\
\hline & & SV & $3.99 \pm 1.14$ & - & - & - & - & $3.99 \pm 1.14$ \\
\hline & & SSV & $4.33 \pm 0.57$ & - & - & - & - & $4.33 \pm 0.57^{\star}$ \\
\hline & & SBV & $3 \pm 0$ & - & $3.33 \pm 2.3$ & - & - & $6.33 \pm 2.23^{\star}$ \\
\hline & \multirow[t]{6}{*}{90 days } & CS & $2.33 \pm 0.57$ & $2 \pm 0$ & - & - & - & $4.33 \pm 0.57$ \\
\hline & & SS & - & - & - & - & - & - \\
\hline & & SB & - & - & - & - & - & All dead \\
\hline & & SV & $4 \pm 0$ & - & $8 \pm 2.82$ & & $12 \pm 4.24$ & $24.0 \pm 3.56^{*}$ \\
\hline & & SSV & $2.66 \pm 1$ & $3.0 \pm 1.73$ & - & - & - & $5.66 \pm 2.33$ \\
\hline & & SBV & $3 \pm 0.57$ & $4 \pm 2$ & $2 \pm 0$ & - & - & $9.0 \pm 2.52^{\star}$ \\
\hline
\end{tabular}

ER, epithelial renovation; GR, accumulation of cytoplasmic granules in hepatic cells; HE, increase in the number of isolated and/or groups of hemocytes; BB, thickening of the brush border; PYC, pycnotic nuclei; CS, control soil; SS, soil + primary sludge; SB, soil + biosolid; SV, soil + vinasse; SSV, soil + primary sludge + vinasse; SBV, soil + biosolid + vinasse.

${ }^{\star}$ Statistically significant at 0.05 level.

against the entry of potentially harmful substances that may be present in the gut lumen. Thus, the epithelial turnover may be a physiological response to remove damaged cells or tissues, in order to maintain the structure of the organ, and prevent changes in its functions by stressors such as the contaminants present in the different residues examined.

Studies carried out by Nogarol \& Fontanetti (2010), Perez \& Fontanetti (2011a), Souza \& Fontanetti (2011), and Merlini et al. (2012) observed an increase in the epithelial turnover rate in the gut of $R$. padbergi, as a response to acute exposure to samples of sewage sludge from different WTPs, an industrial soil contaminated with polycyclic aromatic hydrocarbons, and substrate contaminated with the herbicide trifluralin.
After 30 days, cytoplasmic granules were observed accumulating in hepatic cells as well as a thickening of the brush border in animals of the SB treatment, and increase in the epithelial renovation rate in animals of the SS, SB, and SBV treatments. After 90 days of exposure, these alterations became more severe. For the SB treatment, thickening of the brush border and accumulation of cytoplasmic granules in hepatic cells were observed. The SV treatment was the most harmful to animals, which exhibited an intense epithelial renovation, with shedding of cells into the lumen, hepatic cells with heteropycnotic nuclei, degraded cytoplasm, and clustered hemocytes.

Cell renewal indicates a tissue lesion, with possible replacement of cells in order to maintain the integrity and 
functionality of the tissue. The regeneration of epithelial constituents is a normal physiological process, due to the growth and division of regenerative cells (Hopkin \& Read, 1992). However, epithelial cells exposed to different contaminants are subjected to alterations that may lead to death and consequently their replacement, which may be an attempt by the animal's body to compensate the damage sustained after the ingestion of contaminated soil (Souza \& Fontanetti, 2011).

The layer of hepatic cells works actively in detoxification of the organism when it is harmed by toxic substances (Köhler, 2002). This process was demonstrated with the increase in cytoplasmic granules in individuals exposed to different combinations of residues. The von Kossa staining revealed that part of the cytoplasmic granules in the hepatic cells consists of calcium. The formation of these granules, shown by the ultrastructural analysis, may be due to the absorption of metals and formation of spherocrystals in an attempt to maintain homeostasis and ion balance (Fontanetti et al., 2006; Perez \& Fontanetti, 2011a), as these elements would be inert, avoiding compromising the entire organism.

Studies conducted by Godoy \& Fontanetti (2010), Nogarol \& Fontanetti (2010), and Perez \& Fontanetti (2011a) exposed these same species of diplopod to substrates containing domestic and industrial sewage sludge, and also observed an accumulation of granules in the hepatic cells of these animals.

The increase in hemocytes has also been reported as a frequent response in invertebrates exposed to different toxic agents. According to Perez \& Fontanetti (2011b), in invertebrates, hemocytes play an important role in the recognition of foreign materials to the organism, and can mediate and perform cell defense. This response has also been observed in diplopods exposed to different samples of sewage sludge (Godoy \& Fontanetti, 2010; Nogarol \& Fontanetti, 2010; Perez \& Fontanetti, 2011a), landfarming soil (Souza \& Fontanetti, 2011), and herbicide (Merlini et al., 2012).

In the present study, the increase in hemocytes was observed for SS, SB, and SBV after 30 days of exposure. After 90 days, large clusters of hemocytes were observed in SV. Thus, the occurrence of hemocytes indicates the presence of lesions in the intestine, possibly induced by different metals present in the samples examined, resulting in an inflammatory process. This may be considered a defense mechanism of the organism, which may act in the destruction, dilution, isolation, or sequester of the stressor, in an attempt to allow repair processes, such as regeneration of the damaged tissue (Zweifach et al., 1974). However, the inflammatory process was so severe that heteropycnotic nuclei were observed as well as cytoplasmic degradation of hepatic cells. Pycnotic chromatin, basophilic cytoplasm, and loss of cell boundaries are among the main characteristics of cells undergoing death (Zakeri \& Lockshin, 2002).

Elongation of microvilli of principal cells of animals exposed to SB was observed by electron microscopy. This alteration might have occurred due to contact with the contaminated soil by animals, which did not avoid the toxic substances present and assimilated them during digestion. Studies conducted with enteropathogenic bacteria, Escherichia coli, demonstrated that the elongation and destruction of microvilli of the intestine are involved in the development of food allergies and diarrhea disturbances in animals and humans (Phillips et al., 2000). However, after 30 days of exposure, animals showed signs of the presence of toxic compounds, given the accumulation of spherocrystals and thickening of the brush border. The latter may be an attempt by the animal to prevent the entry of toxic compounds through the intestine.

Thus, examination of the midgut of diplopods exposed to different combinations of sewage sludge, biossolid, and vinasse with histological, histochemical, and ultrastructural analyses provided important information on the effects of this exposure, and which mechanisms may be used by animals in an attempt to detoxify the contaminants present in the different residues applied to the soil. After different periods of exposure, injuries became more severe in the midgut of these animals, and in the field, these animals would be chronically exposed to sludge, biosolid, and vinasse after land application.

\section{CONCLUSION}

The findings demonstrate the efficacy of terrestrial invertebrates in bioprocessing complex environmental samples, as well as use as bioindicators in the evaluation of soil quality, also supporting histological and ultrastructural analysis of the midgut, as biomarkers of stress in these animals. The results obtained indicate the need for further studies on the biological effects of different residues to be disposed in the environment, in the different compartments of ecosystems, as well as in different levels of biological organization, even when toxic agents are present in low concentrations, in order to safely use them in the sustainable conditioning of agricultural soils.

\section{ACKNOWLEDGMENTS}

The authors thank Fundação da Amparo à Pesquisa do Estado de São Paulo-FAPESP (Processes 2009/50578-3, 2009/530479, and 2012/50197-2) and Fundação para o Desenvolvimento da UNESP (FUNDUNESP) for financial support, Américo Sampaio of SABESP-Sanitation Company of the State of Sao Paulo, for allowing the collection of primary sewage sludge and biosolids, Almir José Christofoletti, for collecting sugarcane vinasse, Guilherme Thiago Maziviero and Juliano Liscia Pedroso de Figueiredo for assistance during bioassays, Cristina Moreira de Sousa, Raphael Bastão de Souza and Renato Salaroli, for assistance with photo plates and to Mônika Iamonte for technical assistance.

\section{ReFERENCES}

Artuso, N., Kenedy, T.F., Connery, J., Grant, J. \& Schmidt, O. (2011). Effects of biosolids at varying rates on earthworms (Eisenia fetida) and springtails (Folsomia candida). Appl Env Soil Sci 2011, 1-11.

Bernet, D., Schimidt, H., Meier, W., Burkhardt-Holm, P. \& WAHLI, T. (1999). Histopatology in fish: proposal for a protocol to assess aquatic pollution. J Fish Dis 22, 25-34. 
Bertelli, C. (2007). Efeitos da disposição de lodos de curtume no solo e na planta', 135p. Tese de Doutorado. Universidade Estadual Paulista, Rio Claro, São Paulo. Availabe at http://www. athena.biblioteca.unesp.br/exlibris/bd/brc/33004137036P9/2007/ bertellic_dr_rcla.pdf (retrieved November 20, 2011).

Bettiol, W., Carvalho, P.C.T. \& Franco, B.J.D.C. (1983). Utilização do lodo de esgoto como fertilizante. $O$ solo $75,44-54$.

Bettiol, W. \& GHini, R. (2011). Impacts of sewage sludge in tropical soil: A case study in Brazil. Appl Env Soil Sci 2011, 1-12.

Bozzatto, V. \& Fontanetti, C.S. (2012). Sewage sludge toxicity in edaphic organism: Analysis of midgut responses in the diplopod Rhinocricus padbergi. Microsc Res Techniq 75, 869-875.

Brito, F.L., Rolim, M.M. \& Pedrosa, E.M.R. (2007). Concentração de cátions presente no lixiviado de solos tratados com vinhaça. Eng Agric 27, 773-781.

Camargo-Mathias, M.I., Fantazzini, E.R. \& Fontanetti, C.S. (2004). Ultrastructural features of the midgut of Rhinocricus padbergi (Diplopoda: Spirobolida). Braz J Morphol Sci 21, 65-71.

Camilotti, F., Marques, M.O., Andrioli, I., Silva, A.R., Junior, L.C.T. \& Nobile, F.O. (2007). Acúmulo de metais pesados em cana-de-açúcar mediante a aplicação de lodo de esgoto e vinhaça. Eng Agric 27, 284-293.

Cesar, R.G., Egler, S.G., Polivanov, H., Castilhos, Z.C., Rodrigues, A.P.C. \& Araújo, P.A. (2008). Biodisponibilidade de mercúrio, zinco e cobre em distintas frações granulométricas de solo contaminado utilizando oligoquetas da espécie Eisenia andrei. Anu Inst Geocienc 31, 33-41.

Christofoletti, C.A., Francisco, A. \& Fontanetti, C.S. (2012). Biosolid soil application: Toxicity tests under laboratory conditions. Appl Env Soil Sci 2012, 1-9.

Christofoletti, C.A., Pedro-Escher, J. \& Fontanetti, C.S. (2013). Assessment of the genotoxicity of two agricultural residues after processing by diplopods using the Allium cepa assay. Water Air Soil Pollut 224, 1523-1537.

Cortet, J., Vauflery, A.G., Poinsot-Balaguer, N., Gomot, L., Texier, C. \& Cluzeau, D. (1999). The use of invertebrate soil fauna in monitoring pollutant effects. Eur J Soil Biol 35, 115-134.

Dittbrenner, N., Schmitt, H., Capowiez, Y. \& Triebskorn, R. (2011). Sensitivity of Eisenia fetida in comparison to Aporrectodea caliginosa and Lumbricus terrestris after imidacloprid exposure. Body mass change and histopathology. J Soil Sediment 11, 1000-1010.

EOM, I.M., Rast, C., Veber, A.M. \& VASSEUR, P. (2007). Ecotoxicity of a polycyclic aromatic hydrocarbon (PAH)-contaminated soil. Ecotoxicol Environ Saf 67, 190-205.

Fantazzini, E.R., Fontanetti, C.S. \& Camargo-Mathias, M.I. (2002). Midgut of the millipede, 'Rhinocricus padbergi' Verhoeff, 1938 (Diplopoda: Spirobolida): Histology and histochemistry. Arthropoda Sel 11, 135-142.

Fontanetti, C.S., Christofoletti, C.A., Pinheiro, T.G., Souza, T.S. \& Pedro-Escher, J. (2010). Miscroscopy as a tool in toxicological evaluations. In Microscopy: Science, Technology, Applications and Education, Méndez-Vilas, A. \& Diaz, J. (Eds.), pp. 10011007. Badajoz: Formatex Research Center.

Fontanetti, C.S., Nogarol, L.R., Souza, R.B., Perez, D.G. \& Maziviero, G.T. (2011). Bioindicators and biomarkers in the assessment of soil toxicity. In Soil Contamination, Pascucci, S. (Ed.), pp. 143-159. Rijeka: InTech Europe.

Fontanetti, C.S., Tiritan, B. \& Camargo-Mathias, M.I. (2006). Mineralized bodies in the fat body of Rhinocricus padbergi (Diplopoda) Brazilian. J Morphol Sci 23, 487-493.
Godoy, J.A.P. \& FonTANETTI, C.S. (2010). Diplopods as bioindicators of soils: Analysis of midgut of individuals maintained in substract containing sewage sludge. Water Air Soil Pollut 210, 389-398.

Gonçalves, G.K., Sousa, R.O., VAhl, L.C. \& Bortolon, L. (2008). Solubilização de fosfatos naturais Pato de Minas e Arad em dois solos alagados. Rev. Bras. Ciênc. Solo 32, 2157-2164.

Granato, E.F. \& Silva, C.L. (2002). Geração de energia elétrica a partir do resíduo vinhaça. In Procedings of the 4th Encontro de Energia no Meio Rural, 2002, Campinas (SP) [online]. Available at http://www.proceedings.scielo.br/scielo.php?script=sci_ arttext\&pid=MSC0000000022002000200006 \&lng=en\&nrm=iso (retrieved March 18, 2010).

Hopkin, S.P. \& Read, H.J. (1992). The Biology of Millipedes, 1st ed. New York: Oxford University Press. 233pp.

Junqueira, L.C. \& Junqueira, L.M.M.S. (1983). Técnicas Básicas de Citologia e Histologia. São Paulo: Livraria Editora Santos. 123pp.

KÖHLER, H.R. (2002). Localization of metals in cells of saprophagous soil arthropods (Isopoda, Diplopoda, Collembola). Microsc Res Techniq 56, 393-401.

KöHLER, H.R. \& TriebsKorn, R. (1998). Assessment of the cytotoxic impact of heavy metals on soil invertebrates using a protocol integrating qualitative and quantitative components. Biomarkers 3, 109-127.

LAMBAIS, M.R. \& CARMO, J.B. (2008). Impactos da aplicação de biossólidos na microbiota de solos tropicais. Rev Bras Ciênc Solo 32, 1129-1138.

Lanno, R., Wells, J., Conder, J., Bradham, K. \& Basta, N. (2003). Bioavailability of chemicals in soil for earthworms. Ecotoxicol Environ Saf 57, 39-47.

LøKKe, H. \& VAN GesTel, C.A.M. (1998). Handbook of Soil Invertebrate Toxicity Tests. Chichester: John Wiley and Sons Ltd.

Martins, A.L.C., Bataglia, O.C. \& Camargo, O.A. (2003). Copper, nickel and zinc phytoavailability in an oxisol amended with sewage sludge and liming. Sci Agric 60, 747-754.

Magalhães, M.O.L., Sobrinho, N.M.B.A., Zonta, E., Lima, L.S. \& DE PAiva, F.S.D. (2011). Mobilidade de bário em solo tratado com sulfato de bário sob condição de oxidação e redução. Quim Nova 34, 1544-1549.

McBride, M.B. (1995). Toxic metal accumulation from agricultural use of sludge: Are USEPA regulations protective? J Environ Qual 25, 5-18.

Merlini, V.V., Nogarol, L.R., Marin-Morales, M.A. \& Fontanetti, C.S. (2012). Toxicity of trifluralin herbicide in a representative of the edaphic fauna: Histopathology of the midgut of Rhinocricus pdbergi (Diplopoda). Microsc Res Techniq 75, 1361-1369.

Meyers, T.R. \& Hendricks, J.D. (1985). Histopathology. In Fundamental of Aquatic Toxicology: Methods and Applications, Rand, G.M. \& Petrocelli, S.R. (Eds.), pp. 283-331. New York: Hemisphere Publishing.

Nakamura, K. \& Taira, J. (2005). Distribution of elements in the millipede Oxidus gracilis C. L. Koch (Polydesmida: Paradoxosomatidae) and to relation of environmental habitats. Biometals 18, 651-658.

Nakamura, K., TAira, J. \& Higa, Y. (2005). Internal elements of the millipede, Chamberlinius hualienensis Wang (Polydesmida: Paradoxosomatidae). Appl Entomol Zool 40, 283-288.

Natal da Luz, T., Ribeiro, R. \& Sousa, J.P. (2004). Avoidance tests with collembola and earthworms as early screening tools for site-specific assessment of polluted soils. Environ Toxicol Chem. 23, 2188-2193. 
Nogarol, L.R. \& FontanetTi, C.S. (2010). Acute and subchronic exposure of diplopods to substrate containing sewage mud: Tissular responses of the midgut. Micron 41, 239-246.

Nogarol, L.R. \& FonTANETTI, C.S. (2011). Ultrastructural alterations in the midgut of diplopods after subchronic exposure to substrate containing sewage mud. Water Air Soil Pollut 218, 539-547.

Oliveira, E.L., Andrade, L.A.B., Faria, M.A., Evangelista, A.W.P. \& Morais, A.R. (2009). Uso de vinhaça de alambique e nitrogênio em cana-de-açúcar irrigada e não irrigada. Pesqui Agropecu Bras 44, 1398-1403.

Pearse, A.G.E. (1985). Histochemistry: Theoretical and Apllied, vol. 2, fourth edition. London: J \& A Churchill.

Perez, D.G. \& Fontanetti, C.S. (2011a). Assessment of the toxic potential of sewage sludge in the midgut of the diplopod Rhinocricus padbergi. Water Air Soil Pollut 128, 437-444.

Perez, D.G. \& Fontanetti, C.S. (2011b). Hemocital responses to environmental stress in invertebrates: A review. Environ Monit Assess 177, 437-447.

Petersen, H. \& Luxton, M.A. (1982). Comparative analysis of soil fauna populations and their role in decomposition processes. Oikos 39, 291-357.

Phillips, A.D., Giròn, J., Hicks, S., Dougan, G. \& Frankel, G. (2000). Intimin from enteropathogenic Escherichia coli mediates remodelling of the eukaryotic cell surface. Microbiology 146, 1333-1344.

Schubart, O. (1942). Os Myriapodes e suas relações com a agricultura. Pap Avulsos Zool 2, 205-234.

Silva, M.A.S., Griebeler, N.P. \& Borges, L.C. (2007). Uso de vinhaça e impactos nas propriedades do solo e lençol freático. Rev Bras Eng Agric Ambient 11, 108-114.
Sochová, I., Hofman, J. \& HoloubeK, I. (2006). Using nematodes in soil ecotoxicology. Environ Int 32, 374-383.

SouzA, T.S. \& FontanetTi, C.S. (2011). Morphologial biomarkers in the Rhinocricus padbergi midgut exposed to contamined soil. Ecotoxicol Environ Saf 74, 10-18.

Souza, T.S., Christofoletti, C.A., Bozzatto, V. \& Fontanetti, C.S. (2014). The use of diplopods in soil ecotoxicology-a review. Ecotoxicol Environ Saf 103, 68-73.

Stevenson, F.J. (1982). Humus Chemistry: Genesis, Composition, Reaction. New York: John Wiley. 496 pp.

Suthar, S. (2010). Pilot-scale vermireactors for sewage sludge stabilization and metal remediation process: Comparison with small-scale vermireactors. Ecol Eng 36, 703-712.

Triebskorn, R., Henderson, I.F. \& Martin, A.P. (1999). Detection of iron in tissues from slugs (Deroceras reticulatum Müller) after ingestion of iron chelates by means of energy-filtering transmission electron microscopy (EFTEM). Pest Manag Sci 55, 55-61.

Triebskorn, R., Köhler, H.R., Zanh, T., Vogt, G., Ludwing, M., Rumpf, S., Kratzmann, M., Alberti, G. \& Storch, V. (1991). Invertebrate cells as targets for hazardous substances. Zeitschfirt fuer Angewandte Zoologie 78, 277-287.

VANZO, J.E., MACEDO, L.S. \& TsuTiYA, M.T. (2010). ETE Franca: uma estação que além de tratar os esgotos, produz insumos agrícolas. In XXVII Congresso Interamericano de Engenharia Sanitária e Ambiental, pp. 1-14. Available at http://www.cepis.org.pe/ bvsaidis/aresidua/i-084.pdf (retrieved March 18, 2010).

WALKER, J. (1976). Host defense mechanisms in the gastrointestinal tract. Pediatrics 57, 901-916.

ZAKERI, Z. \& LOCKSHIN, R.A. (2002). Cell death during development. J Immunol Methods 265, 3-20.

Zweifach, B.W., Grant, L. \& Mccluskey, R.T. (1974). The Inflammatory Process. New York: Academic Press. 419pp. 